\title{
USE OF SUGAR APPLE, ATEMOYA AND SOURSOP FOR TECHNOLOGICAL DEVELOPMENT OF JAMS - CHEMICAL AND SENSORIAL COMPOSITION
}

\author{
Aproveitamento tecnológico da fruta do conde, atemóia e graviola para elaboração de \\ geleias - composição química e sensorial
}

\author{
Daniela Castilho Orsi', Vania Silva Carvalho², Adriana Cândida Faustino Nishi \\ Clarissa Damiani ${ }^{2}$, Eduardo Ramirez Asquieri ${ }^{3}$
}

\begin{abstract}
Sugar apple, atemoya and soursop are tropical fruits very prized for their pleasant, aromatic and distinctive flavor. In this work, the fresh fruits pulps had high nutritional values, since they contain significant levels of carbohydrates. The results for the analysis of chemical composition of the fresh fruits pulps obtained for sugar apple, atemoya and soursop were respectively: moisture $\left(79.65,77.06\right.$ and $\left.85.30 \mathrm{~g} .100 \mathrm{~g}^{-1}\right)$, carbohydrates $\left(20.52,22.01\right.$ and $\left.13.83 \mathrm{~g} .100 \mathrm{~g}^{-1}\right)$, total sugars $(19.57,21.93$ and 10.12 g. $\left.100 \mathrm{~g} \mathrm{~g}^{-1}\right)$ and soluble solids $\left(22.00,25.10\right.$ and $12.83{ }^{\circ}$ Brix). With the aim of processing the pulps of ripe fruits to add value to these fruits, jams have been developed. The results for the chemical composition analysis of sugar apple, atemoya and soursop

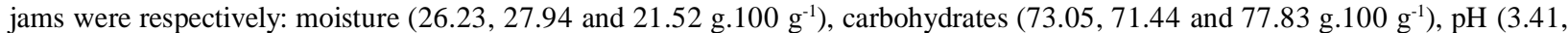
3.34 and 3.41) and soluble solids $\left(63.00,65.00\right.$ and $68.60^{\circ}$ Brix). The jams were subjected to Quantitative Descriptive Analysis. A total of 12 trained panelists evaluated the attributes flavor, consistency, appearance and overall acceptability of the jams on a 9-point hedonic scale. Based on sensory evaluation, jams presented a good overall acceptability and atemoya jam was the most preferred by the panelists.
\end{abstract}

Index terms: Tropical fruits, nutritional value, annonaceae.

\section{RESUMO}

Fruta do conde, atemóia e graviola são frutos tropicais muito apreciados por seu sabor agradável, aromático e marcante. Neste trabalho, constatou-se que as polpas de frutas frescas tiveram altos valores nutricionais, uma vez que estas continham níveis significativos de carboidratos. Os resultados para a análise da composição química das polpas de frutas frescas, obtidos para fruta do conde, atemóia e graviola foram respectivamente: umidade $\left(79,65,77,06\right.$ e $\left.85,30 \mathrm{~g} .100 \mathrm{~g}^{-1}\right)$, carboidratos $(20,52,22,01 \mathrm{e} 13,83$ g.100 g $\left.\mathrm{g}^{-1}\right)$, açúcares totais $\left(19,57,21,93\right.$ e $\left.10,12 \mathrm{~g} .100 \mathrm{~g}^{-1}\right)$ e sólidos solúveis $\left(22,00\right.$ 25,10 e 12,83 ${ }^{\circ}$ Brix $)$. Com o objetivo de processar as frutas maduras para agregar valor a essas frutas, geleias foram desenvolvidas. Os resultados da análise da composição química das geleias de pinha, atemóia e graviola foram respectivamente: umidade $\left(26,23,27,94\right.$ e 21,52 g.100 g $\left.\mathrm{g}^{-1}\right)$, carboidratos (73,05, 71,44 e 77,83 g.100 g-1), pH (3,41, 3,34 e 3,41) e sólidos solúveis $\left(63,00,65,00\right.$ e 68,60 ${ }^{\circ}$ Brix). As geleias foram submetidas à Análise Descritiva Quantitativa. Um total de 12 provadores treinados avaliaram os atributos sabor, consistência, aparência e aceitabilidade global das geleias em uma escala hedônica de 9 pontos. Baseado na avaliação sensorial, as geleias apresentaram uma boa aceitação global e a geleia de atemóia foi à preferida dos provadores.

Termos para indexação: Frutos tropicais, valor nutricional, anonáceas.

\section{(Received in august 1, 2012 and approved in september 12, 2012)}

\section{INTRODUCTION}

The Annonaceae includes approximately 50 genera. The main commercial species are the cherimoya (Annona cherimola Mill.), the hybrid atemoya (Annona cherimola Mill. $x$ Anonna squamosa L.), the sugar apple or sweetsop (Anonna squamosa L.), known as pinha, ata or fruta do conde in Brazil and the soursop (Annona muricata L.), known as graviola in Brazil. The generic term 'custard apple' is to the first three fruits. Both species are cultivated throughout the tropical and subtropical regions of South America (SILVA et al, 2009; LIMA et al., 2006).

The fruits of sugar apple, atemoya and soursop are oval or heart-shaped with tender soft pliable spines which breakup easily when the fruit is ripe. Soursop fruits are bigger, larger and could weigh as much as $3.5 \mathrm{~kg}$ while

\footnotetext{
1Universidade de Brasília/UNB - Faculdade de Ceilandia/FCE - Centro Metropolitano de Ceilândia - Conjunto A lote 01 - Provisório - QNN 14 - Área Especial Ceilândia Sul - 72220-140 - Brasilia - DF - Brasil -dropsdani@yahoo.com.br

'2Universidade Federal de Goiás/UFG - Escola de Agronomia e Engenharia de Alimentos - Goiânia - GO - Brasil

${ }^{3}$ Universidade Federal de Goiás/UFG - Faculdade de Farmácia - Goiânia - GO - Brasil
}

Ciênc. agrotec., Lavras, v. 36, n. 5, p. 560-566, set./out., 2012 
sugar apple and atemoya fruits weigh about $0.1-0.15 \mathrm{~kg}$ (SACRAMENTO et al., 2003; NWOKOCHA; WILLIAMS, 2009).

Like most tropical fruits, the sugar apple, the atemoya and the soursop have a great potential for exportation and they are able to compete in the international market. They are popular fruits of tropical regions and prized for its very pleasant, sub-acid, aromatic, juicy flesh and distinctive flavor. When ripe, pulps are creamy, very sweet and pleasantly flavored. However, these fruits soften very rapidly during ripening and become difficult to consume fresh. They are commonly rejected at market because of external injury or uneven shape and size. Therefore, incorporation of these tropical fruits pulps into nectars, jams and ice creams is a way to exploit their exotic flavors (LIMA et al., 2001; NEVES; YUHARA, 2003; UMME et al., 2001).

Jam processing is a fruit preservation method and adds value to overripe fruits. In Brazil the most common commercial tropical fruits jams are made with guava, mango and jaboticaba. There is no commercial jam of sugar apple, atemoya and soursop. So, the objectives of this study were to evaluate the chemical characteristics of the fruits sugar apple, atemoya and soursop, to develop jams with the fresh fruits pulps and to evaluate the sensory properties of the three prepared jams, in order to test the consumer reaction to these new products.

\section{MATERIALS AND METHODS}

\section{Fruits samples}

Sugar apple (Anonna squamosa L.), atemoya (Annona cherimola Mill. $x$ Anonna squamosa L.) and soursop (Anonna squamosa L.) fruits were acquired between July and September 2010 at the Storage Center (CEASA, Goiânia, GO, Brazil) and fruits were from the southwest region of the State of São Paulo. The ripe fruits were selected, washed in running water, treated in a solution of sodium hypochlorite ( $200 \mathrm{ppm}$ ) for 15 minutes, rinsed and opened approximately into two equal halves and the pulps were scooped using stainless-steel spoons. Subsequently the pulps were deseeded and the resulting pulps were stored at " $18^{\circ} \mathrm{C}$ until analysis.

\section{Chemical analyses}

The chemical composition analyses in fresh fruits pulps and in jams were conducted at the Laboratory of Food Chemistry and Biochemistry of the Faculty of Pharmacy - Federal University of Goiás - Brazil. The ash content was determined by calcination in a muffle furnace at $550^{\circ} \mathrm{C}$, model EDGCON 3P 3000 (EDGEquipments, São
Carlos, SP, Brazil) to constant weight. Moisture content was determined by drying in stove at $105^{\circ} \mathrm{C}$ for 4 hours to constant weight (ASSOCIATION OF OFFICIAL ANALYTICALCHEMISTS-AOAC, 2006). Total nitrogen was determined by micro-Kjeldahl method and the nitrogen percentage was converted into crude protein by multiplying by the conversion factor of 6.25 (AOAC, 2006). Total lipids were determined by the Bligh \& Dyer (1959) method. The total carbohydrates content was determined according to Dubois et al. (1956) and the total caloric value was estimated using the Atwater conversion values described by Wilson et al. (1982) and the results expressed in kcal. Reducing sugars were determined using the 3,5-dinitrosalicylic acid method (MILLER, 1959). To determine the sucrose content, the 3,5-dinitrosalicylic acid method was used, with modifications proposed by Silva et al., 2003. The results were expressed as percentages $\left(\mathrm{g} .100 \mathrm{~g}^{-1}\right)$. The soluble solids were determined through benchtop refractometer SHIMADZU and expressed in ${ }^{\circ}$ Brix. The $\mathbf{p H}$ was measured using a digital potentiometer Micronal B222, introducing the electrode directly into the jam and total acidity was determined by titration with $0.1 \mathrm{~N} \mathrm{NaOH}$ (AOAC, 2006). Each parameter was analyzed in triplicate. Results are shown as mean values and standard deviation of the independent determinations. One-way analysis of variance (ANOVA) was used to compare the means. Differences were considered significant at $\mathrm{p}<0.05$. All statistical analyses were performed with the software STATISTICA (data analysis software system, Version 7.1; Stat Soft, Tulsa, OK).

\section{Jams processing}

The jams of sugar apple, atemoya and soursop were prepared by cooking at $100^{\circ} \mathrm{C}$ the fruit purees with sucrose and pectin until $65^{\circ}$ Brix. Fruits purees were obtained by homogenization of the freshly pulps using a blender. Jams, known as extra-type jam, 50\% fruit and 50\% sugar, were formulated using the method described in the jam manufacturing manual (LOPES, 1985). About $100 \mathrm{~g}$ of sucrose were added to $100 \mathrm{~g}$ of freshly fruit puree. Commercial high methoxyl content - HCM pectin ( $1.5 \mathrm{~g}$ ) was dispersed in 45 $\mathrm{g}$ sucrose. At the beginning of boiling, the pectin dispersed in sucrose was poured into the mixture. Samples were cooked to about $65^{\circ}$ Brix in an open kettle, with manual stirring. Soluble solids content ( ${ }^{\circ}$ Brix) was determined at $25^{\circ} \mathrm{C}$ using a benchtop refractometer SHIMADZU. The $\mathrm{pH}$ was adjusted at the end of cooking to about 3.2-3.4 with a citric acid solution $(10 \%, \mathrm{w} / \mathrm{v})$. Then, the jams were poured into $200 \mathrm{~g}$ sterile glass jars, packed, immediately cooled to room temperature 
and stored for 5 days at ambient temperature for subsequent chemical analyses.

\section{Sensory evaluation of jams}

The jams were subjected to Quantitative Descriptive Analysis (QDA). A total of 12 trained panelists of both sexes and aged between 20-27 years participated in the study. The panelists were selected by screening for ability to describe and discriminate sensory attributes of the jams, according to Stone \& Sidel (1993). The first step was to expose the panelists to a wide range of products from the product category to be assessed. Each panelist individually lists as many descriptive words possible that describe differences between the products. During the trial sessions, reference materials (commercial jams) were presented to give notions of quantitative and qualitative attributes. The reference materials were obtained by acquiring several flavors of jams in the local market, with wide variations in quality. Then, the panel leader evaluated the results, discussed and identified the relevant sensory characteristics of the product and the panelists reached a consensus on the attributes, their meanings and the sequence of evaluation of each. Flavor, consistency, appearance and overall acceptability of jams were evaluated following nine point hedonic scale $(9=$ like extremely, $8=$ like very much, $7=$ like moderately, $6=$ like slightly, $5=$ neither like nor dislike, $4=$ dislike slightly, $3=$ dislike moderately, 2 = dislike very much, $1=$ dislike extremely) (MONTEIRO, 1984). The panelists also responded purchase intention of jams. All samples were presented before the panelists at room temperature $\left(25^{\circ} \mathrm{C}\right)$ under normal lighting conditions in $50 \mathrm{~mL}$ cups coded with random, three-digit numbers. Bread pieces and spoons were provided to the panelists. Drinking water was provided for oral rinsing.

\section{RESULTS AND DISCUSSION}

\section{Chemical analyses of fruits}

The averages of the triplicate measurements of chemical analyses of atemoya, sugar apple and soursop fruits pulps are shown in table 1 . There were significant differences $(\mathrm{p}<0.05)$ among the characteristics for the three fruits tested. In general, the values for chemical characteristics of atemoya, sugar apple and soursop corresponded to the literature.

Moisture had mean values of 77.06, 79.65 and 85.30 g. $100 \mathrm{~g}^{-1}$ for atemoya, sugar apple and soursop, respectively. Marcellini et al. (2003) obtained similar results of $75.55,77.20$ and $88.33 \mathrm{~g} .100 \mathrm{~g}^{-1}$ for the same fruits (atemoya, sugar apple and soursop, respectively). The second principal component was the carbohydrates, which represented approximately 14-22 g.100 g $\mathrm{g}^{-1}$ of the total composition. Total sugar of sugar apple (19.57 g.100 g $\left.\mathrm{g}^{-1}\right)$ was similar to the value found by Gomes (1987) (18.15 g.100 $\left.\mathrm{g}^{-1}\right)$. Total sugar of soursop $\left(10.12 \mathrm{~g} .100 \mathrm{~g}^{-1}\right)$ was lower than values reported by Sacramento et al. (2003) (12.53$\left.14.55 \mathrm{~g} .100 \mathrm{~g}^{-1}\right)$ and higher than value reported by Umme et al. (2001) (7.59 g.100 g $\mathrm{g}^{-1}$ ). This might be caused by differences in fruit cultivar and stages of maturity. The fruits showed low fat $\left(0.38-0.58 \mathrm{~g} .100 \mathrm{~g}^{-1}\right)$ and low protein (0.96-1.60 g. $\left.100 \mathrm{~g}^{-1}\right)$ contents.

Table 1 - Chemical composition of fruits pulps.

\begin{tabular}{lccc}
\hline & Sugar apple & Atemoya & Soursop \\
\hline Moisture $\left(\mathrm{g} .100 \mathrm{~g}^{-1}\right)$ & $79.65 \pm 0.12 \mathrm{~b}$ & $77.06 \pm 0.23 \mathrm{c}$ & $85.30 \pm 0.19 \mathrm{a}$ \\
Ash $\left(\mathrm{g} .100 \mathrm{~g}^{-1}\right)$ & $0.67 \pm 0.06 \mathrm{a}$ & $0.56 \pm 0.01 \mathrm{ab}$ & $0.48 \pm 0.05 \mathrm{~b}$ \\
Protein $\left(\mathrm{g} .100 \mathrm{~g}^{-1}\right)$ & $1.60 \pm 0.07 \mathrm{a}$ & $0.56 \pm 0.01 \mathrm{c}$ & $0.96 \pm 0.01 \mathrm{~b}$ \\
Total lipid $\left(\mathrm{g} .100 \mathrm{~g}^{-1}\right)$ & $0.47 \pm 0.03 \mathrm{~b}$ & $0.38 \pm 0.03 \mathrm{c}$ & $0.58 \pm 0.01 \mathrm{a}$ \\
Carbohydrate $\left(\mathrm{g} .100 \mathrm{~g}^{-1}\right)$ & $20.52 \pm 0.02 \mathrm{~b}$ & $22.01 \pm 0.03 \mathrm{a}$ & $13.83 \pm 0.03 \mathrm{c}$ \\
Total sugar $\left(\mathrm{g} .100 \mathrm{~g}^{-1}\right)$ & $19.57 \pm 0.13 \mathrm{~b}$ & $21.93 \pm 0.15 \mathrm{a}$ & $10.12 \pm 0.17 \mathrm{c}$ \\
Reducing sugars $\left(\mathrm{g} .100 \mathrm{~g}^{-1}\right)$ & $18.72 \pm 0.07 \mathrm{~b}$ & $21.93 \pm 0.15 \mathrm{a}$ & $9.91 \pm 0.04 \mathrm{c}$ \\
Sucrose $\left(\mathrm{g} .100 \mathrm{~g}^{-1}\right)$ & $0.85 \pm 0.10 \mathrm{a}$ & $0.00 \mathrm{c}$ & $0.21 \pm 0.01 \mathrm{~b}$ \\
pH & $5.66 \pm 0.13 \mathrm{a}$ & $4.56 \pm 0.08 \mathrm{~b}$ & $3.78 \pm 0.15 \mathrm{c}$ \\
Total acidity $\left(\mathrm{g} .100 \mathrm{~g}^{-1}\right)$ & $0.21 \pm 0.01 \mathrm{c}$ & $0.54 \pm 0.06 \mathrm{~b}$ & $0.91 \pm 0.01 \mathrm{a}$ \\
Soluble solids $\left({ }^{\circ} \mathrm{Brix}\right)$ & $22.00 \pm 0.05 \mathrm{~b}$ & $25.10 \pm 0.11 \mathrm{a}$ & $12.83 \pm 0.05 \mathrm{c}$ \\
Caloric value $\left(\mathrm{kcal} \mathrm{x} 100 \mathrm{~g}^{-1}\right)$ & 92.98 & 93.68 & 64.38 \\
\hline
\end{tabular}

Results are reported as means \pm standard deviation of three measurements and are expressed in fresh weight basis. Means in the same row with different letters are significantly different at $\mathrm{p}<0.05$.

Ciênc. agrotec., Lavras, v. 36, n. 5, p. 560-566, set./out., 2012 
In this study, sugar apple had mean values of 0.21 g. $100 \mathrm{~g}^{-1}$ for total acidity, 5.66 for $\mathrm{pH}$ and $22.00{ }^{\circ}$ Brix for soluble solids. Marcellini et al. (2003) analyzed the fruit sugar apple and obtained similar values for total acidity $\left(0.18 \mathrm{~g} .100 \mathrm{~g}^{-1}\right)$ and $\mathrm{pH}(5.48)$ and a higher value for soluble solids $\left(27.53^{\circ}\right.$ Brix $)$. Atemoya, in this study, had mean values of $0.54 \mathrm{~g} .100 \mathrm{~g} \mathrm{~g}^{-1}$ for total acidity, 4.56 for $\mathrm{pH}$ and $25.10^{\circ}$ Brix for soluble solids. Silva et al. (2009) obtained similar results for atemoya fruits after 9 days of cold storage ( $0.23 \mathrm{~g} .100$ $\mathrm{g}^{-1}$ for total acidity, 4.75 for $\mathrm{pH}$ and $25.42^{\circ}$ Brix for soluble solids). Neves \& Yuhara (2003) evaluated some physicochemical characteristics of four atemoya cultivars. The total acidity and soluble solids contents of different atemoya cultivars ranged between $0.17-0.30 \mathrm{~g} .100 \mathrm{~g}^{-1}$ and 16.4-25.8 ${ }^{\circ}$ Brix, respectively.

Atemoya and sugar apple had higher soluble solids and $\mathrm{pH}$ values and lower total acidity values than soursop that had mean values of $0.91 \mathrm{~g} .100 \mathrm{~g}^{-1}$ for total acidity, 3.78 for $\mathrm{pH}$ and $12.83^{\circ} \mathrm{Brix}$ for soluble solids. Marcellini et al. (2003) obtained similar values for soursop: 0.58 g. $100 \mathrm{~g}^{-1}$ for total acidity, 4.36 for $\mathrm{pH}$ and $12.21{ }^{\circ}$ Brix for soluble solids. Sacramento et al. (2003) evaluated some physicochemical characteristics of three soursop cultivars. The total acidity, $\mathrm{pH}$ and soluble solids contents of different soursop cultivars ranged between $0.92-1.00$ g.100 $\mathrm{g}^{-1}, 3.44-3.47$ and $12.18-13.85^{\circ}$ Brix, respectively. Lima et al. (2003) evaluated the physicochemical changes of soursop after harvest at physiological maturity and stored at ambient temperature for 6 days. After 6 days of storage it was obtained values of $0.88 \mathrm{~g} .100 \mathrm{~g}^{-1}$ for total acidity, 3.60 for $\mathrm{pH}$ and $14.40^{\circ}$ Brix for soluble solids.
In all fruits, low values for total acidity and high values for soluble solids and total sugar (fructose and glucose) were found. These characteristics were consistent with decomposition of complex carbohydrates and organic acids typically associated with the Annonaceae fruits ripening, which present very sweet flavor.

\section{Chemical analyses of jams}

Chemical analyses of jams were made 5 days after processing. The averages of the triplicate measurements of chemical analyses of atemoya, sugar apple and soursop jams are shown in table 2. Jams presented low moisture and had soluble solids mean values of 63.00, 65.00 and $68.00{ }^{\circ}$ Brix for sugar apple, atemoya and soursop, respectively. According to brazilian legislation, jams should contain a minimum of $62-65^{\circ}$ Brix for soluble solids and a maximum of 35-38 g.100 g ${ }^{-1}$ for moisture (BRASIL, 1978).

Sugars in jams contribute to high content of soluble solids, an effect that is essential for the physical, chemical and microbiological stability and make gelation of pectin possible. Sucrose reduces water activity, thus the spoilage organisms in jams do not survive. Total sugars, reducing sugars and sucrose contents of atemoya, sugar apple and soursop jams ranged between $49.90-56.19 \mathrm{~g} .100 \mathrm{~g} \mathrm{~g}^{-1}, 12.38-21.40 \mathrm{~g} .100 \mathrm{~g}^{-1}$ and 29.81-44.10, respectively. The mean values of total sugars $(56.19 \mathrm{~g} .100$


g. $100 \mathrm{~g}^{-1}$ ) for soursop jam were similar to the results obtained by Granada et al. (2005) for pineapple control formulation jam: $63.04 \mathrm{~g} .100 \mathrm{~g}^{-1}$ for total sugars, $20.02 \mathrm{~g} .100$ $\mathrm{g}^{-1}$ for reducing sugars and $40.86 \mathrm{~g} .100 \mathrm{~g}^{-1}$ for sucrose.

Table 2 - Chemical composition of jams.

\begin{tabular}{|c|c|c|c|}
\hline & Sugar apple & Atemoya & Soursop \\
\hline Moisture (g.100 g $\left.\mathrm{g}^{-1}\right)$ & $26.23 \pm 0.02$ & $27.94 \pm 0.03$ & $21.52 \pm 0.02$ \\
\hline $\operatorname{Ash}\left(\mathrm{g} .100 \mathrm{~g}^{-1}\right)$ & $0.11 \pm 0.01$ & $0.07 \pm 0.02$ & $0.08 \pm 0.01$ \\
\hline Protein $\left(\mathrm{g} .100 \mathrm{~g}^{-1}\right)$ & $0.36 \pm 0.02$ & $0.49 \pm 0.01$ & $0.32 \pm 0.01$ \\
\hline Total lipid (g.100 g $\left.\mathrm{g}^{-1}\right)$ & $0.13 \pm 0.02$ & $0.11 \pm 0.16$ & $0.25 \pm 0.03$ \\
\hline Carbohydrate (g.100 g $\left.\mathrm{g}^{-1}\right)$ & $73.05 \pm 0.05$ & $71.44 \pm 0.02$ & $77.83 \pm 0.04$ \\
\hline Caloric value ( $\left.\mathrm{kcal} x 100 \mathrm{~g}^{-1}\right)$ & $294.83 \pm 0.13$ & $288,71 \pm 0.15$ & $314.85 \pm 0.10$ \\
\hline Total sugar (g.100 g $\left.\mathrm{g}^{-1}\right)$ & $51.21 \pm 0.15$ & $49.90 \pm 0.03$ & $56.19 \pm 0.13$ \\
\hline Reducing sugars (g.100 g $\left.\mathrm{g}^{-1}\right)$ & $21.40 \pm 0.01$ & $19.33 \pm 0.01$ & $12.38 \pm 0.06$ \\
\hline Sucrose $\left(\mathrm{g} .100 \mathrm{~g}^{-1}\right)$ & $29.81 \pm 0.13$ & $30.57 \pm 0.02$ & $44.10 \pm 0.05$ \\
\hline $\mathrm{pH}$ & $3.41 \pm 0.01$ & $3.34 \pm 0.01$ & $3.41 \pm 0.01$ \\
\hline Total acidity (g.100 g $\left.{ }^{-1}\right)$ & $0.56 \pm 0.01$ & $0.49 \pm 0.01$ & $0.46 \pm 0.01$ \\
\hline Soluble solids ( ${ }^{\circ}$ Brix) & $63.00 \pm 0.05$ & $65.00 \pm 0.01$ & $68.60 \pm 0.01$ \\
\hline
\end{tabular}

Results are reported as means \pm standard deviation of three measurements and are expressed in fresh weight basis. 
Singh et al. (2009) studied different fruits pulps (banana and papaya) and fruits juices (orange and pineapple) combinations to obtain mixed fruit jams. Total sugars contents ranged between $35.00-54.55 \mathrm{~g} .100 \mathrm{~g}^{-1}$ and

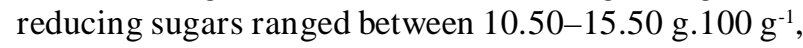
for different mixed fruit jams. The caloric values of jams (294.83-314.85 kcal.100g-1) were similar to araçá jam $\left(285.04 \mathrm{kcal} 100 \mathrm{~g}^{-1}\right)$ and the total carbohydrate contents increased the caloric values of the jams (DAMIANI et al., 2012).

The total acidity and the $\mathrm{pH}$ of the finished products ranged between $0.46-0.56 \mathrm{~g} .100 \mathrm{~g}^{-1}$ and 3.343.41 , respectively. It is known that the acidity and $\mathrm{pH}$ of jams should be controlled. The low acidity (0.3-0.8 g.100 $\left.\mathrm{g}^{-1}\right)$ and low $\mathrm{pH}(3.2-3.4)$ contribute to pectin gelation and increase the stability of the formulated jams (LAGO et al., 2006). However, the $\mathrm{pH}$ must not be too low $(<3.0)$ since it could induce deterioration of sensory quality: excessive acidic flavor, glucose crystallization; granular texture and exudation phenomenon (FERREIRA et al., 2004).

The mean values of moisture (27.94\%), soluble solids $\left(65^{\circ}\right.$ Brix $)$, total acidity $\left(0.49 \mathrm{~g} .100 \mathrm{~g}^{-1}\right)$ and $\mathrm{pH}$ (3.34) for atemoya jam were similar to the results obtained by Lago; Gomes; Silva (2006) for jambolan jam: $29.66 \mathrm{~g} .100 \mathrm{~g}^{-1}$ for moisture, $67^{\circ}$ Brix for soluble solids, $0.55 \mathrm{~g} .100 \mathrm{~g}^{-1}$ for total acidity, and 3.41 for pH. García-Martínez et al. (2002) analyzed a commercial traditional kiwifruit jam and obtained the results of $68.40^{\circ}$ Brix for soluble solids, $0.46 \mathrm{~g} .100 \mathrm{~g}^{-1}$ for total acidity and 3.04 for $\mathrm{pH}$ and the results of the commercial orange jam $\left(63.90^{\circ}\right.$ Brix for soluble solids and 3.63 for $\mathrm{pH}$ ) were similar to the results obtained for sugar apple jam $\left(63.00{ }^{\circ}\right.$ Brix for soluble solids, and 3.41 for $\mathrm{pH}$ ). Maciel et al (2009) developed a mixed fruit mango and acerola jam and obtained results of 63.50-64.00 ${ }^{\circ}$ Brix for soluble solids and 3.4-3.5 for $\mathrm{pH}$. According to data presented, the jams of sugar apple, atemoya and soursop had a good processing technology, since their composition results were similar to those reported in other studies with fruit jams.

\section{Sensory evaluation of jams}

The results of sensory evaluation of atemoya, sugar apple and soursop jams are shown in table 3. The soursop jam had the lowest score in flavor and overall acceptability, but did not differ significantly among the other jams. There was no statistically significant difference $(\mathrm{p}<0.05)$ between jams in flavor and appearance. The attribute consistency of atemoya jam significantly differed from sugar apple jam and was what most pleased the judges (average score 7.83), suggesting this jam was left with an appropriate texture of the gel. The consistency of sugar apple and atemoya jams had average scores of 5.67 and 6.42 , indicating that the pectin concentration could be higher, because the fruits used in the preparation of the jams were ripe, which results in decrease of the natural fruit pectin.

Table 3 - Averages scores for the sensory attributes of jams.

\begin{tabular}{lccl}
\hline Attributes & Sugar apple & Atemoya & Soursop \\
\hline Flavor & $7.09 \mathrm{a}$ & $7.54 \mathrm{a}$ & $7.00 \mathrm{a}$ \\
Consistency & $5.67 \mathrm{a}$ & $7.83 \mathrm{~b}$ & $6.42 \mathrm{a}, \mathrm{b}$ \\
Appearance & $6.17 \mathrm{a}$ & $7.67 \mathrm{a}$ & $6.33 \mathrm{a}$ \\
Overall & $7.17 \mathrm{a}$ & $7.67 \mathrm{a}$ & $7.00 \mathrm{a}$ \\
acceptability & & & \\
\hline
\end{tabular}

Means in the same row followed by same letter did not significantly differ at $\mathrm{p}<0.05$ by Tukey's test.

Based on sensory evaluation of jams, atemoya jam was the most preferred. The sensory profile of the jams (Figure 1) shows that atemoya jam had higher total scores than other jams and the attributes consistency, appearance and overall impression were rated close to 8.0 (like very much). Although the atemoya pulp not have a color intense, this jam had a good natural orange color appearance and had a better balance between acidity and sweetness, resulting in a milder and pleasant flavor.

There was no statistically significant difference between jams for the overall acceptability. The jams of atemoya, sugar apple and soursop reached acceptance index of $85.22 \%, 79.67 \%$ and $77.78 \%$, respectively, based on overall acceptability. According to Teixeira et al. (1987) to be a product acceptable in terms of sensory properties, it is necessary to obtain an acceptance index of at least $70.00 \%$. The majority of the panelists, $75.00 \%$ and $66.67 \%$, certainly would purchase the sugar apple and soursop jams, respectively, confirming the good acceptability of these products. No rejection was observed for atemoya jam, which means that $100 \%$ of the panelists certainly would purchase this product. 


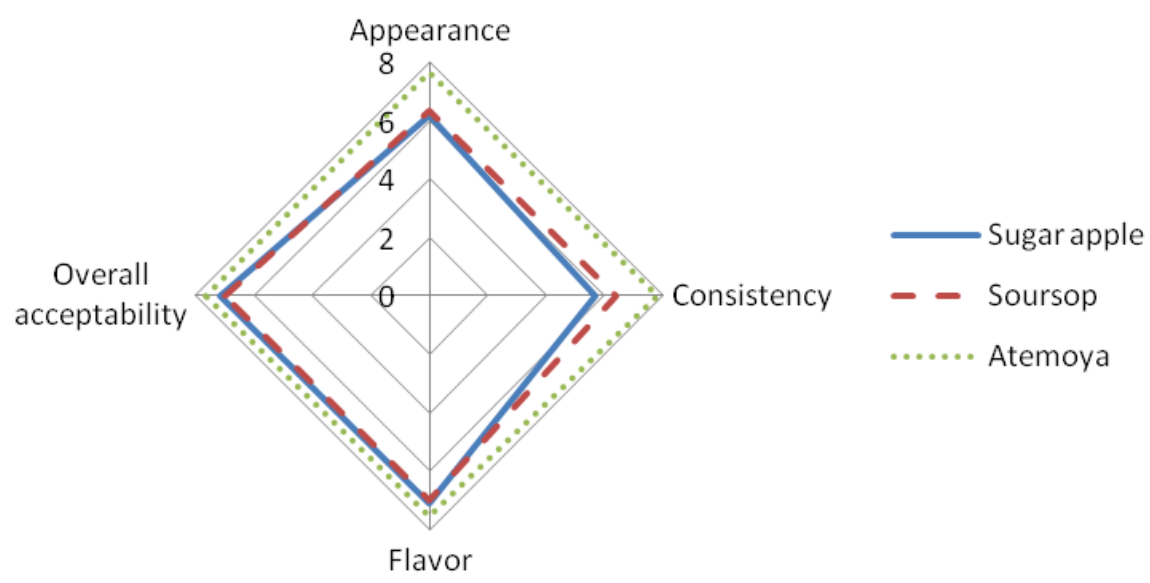

Figure 1 - Sensory profile of sugar apple, atemoya and soursop jams.

\section{CONCLUSIONS}

The jams of atemoya, sugar apple and soursop showed good processing technology and good acceptability, what could be an alternative for the conservation of these tropical fruits, which represents a possible alternative to add value and expand their use throughout the consumer market. Atemoya jam was the most preferred by the panelists with an acceptance index of $85.22 \%$ for overall acceptability and $100 \%$ of the panelists reported that they possibly would purchase the product if available in the market.

\section{REFERENCES}

ASSOCIATION OF OFFICIALANALYTICAL CHEMISTS - AOAC. Official methods of analysis. 18rd ed.Gaithersburg: AOAC; 2006.

BLIGH, E. G.; DYER, W. J. A rapid method of lipid extraction and purification. Canadian Journal of Biochemistry and Physiology, Ottawa, v.37, n.8, p.911917, 1959.

BRASIL - Agência Nacional de Vigilância Sanitária. Resolução normativa n. 12, de 24/07/1978. Comissão Nacional de Normas e Padrões para Alimentos, 1978. Disponível em: http://www.anvisa.gov.br/legis/resol/ 12_78.pdf. Acesso em: 02 de Janeiro de 2012.

DAMIANI, C. et al. Antioxidant potential of Psidium guinnensis Sw. jam during storage. Pesquisa Agropecuária Tropical, Goiânia, v.42, n.1, p.90-98, 2012.
DULBOIS, M. K. A. et al. Colorimetric method for determination of sugars and related substances, Analytical Chemistry, Washington, v.28, n.3, p. 350-355, 1956.

FERREIRA, I. et al. Quince jam quality: microbiological, physicochemical and sensory evaluation, Food Control, Vurrey, v.15, n.4, p.291-295, 2004.

GARCÍA-MARTÍNEZ, E. et al. Jam manufacture with osmodehydrated fruit, Food Research International, Essex, v.35, n.2-3, p.301-306, 2002.

GOMES, P. Fruticultura Brasileira. 11ed. São Paulo: Nobel, 1987. 446p.

GRANADA, G. G. et al. Caracterização física, química, microbiológica e sensorial de geléias light de abacaxi. Ciência e Tecnologia de Alimentos, Campinas, v.25, n. 4, p.629-635, 2005.

LAGO, E. S.; GOMES, E.; SILVA, R. Produção de geleia de jambolão (Syzygium cumini Lamarck): processamento, parâmetros físico-químicos e avaliação sensorial, Ciência e Tecnologia de Alimentos, Campinas, v.26, n.4, p.847-856, 2006.

LIMA, M. A. C.; ALVES, R. E.; FILGUEIRAS, H. A. C. Mudanças relacionadas ao amaciamento da graviola durante a maturação pós-colheita, Pesquisa

Agropecuária Brasileira, Brasília, v.41, n.12, p. 1707$1713,2006$. 
LIMA, M. A. C. et al. Comportamento respiratório e qualidade pós-colheita de graviola (Annona muricata L.) 'morada' sob temperatura ambiente, Revista Brasileira de Fruticultura, Jaboticabal, v.25, n.1, p. 49-52, 2003.

LIMA, E. D. P. A.; PASTORE, G. M.; LIMA, C. A. A. Purificação da enzima polifenoloxidase (PFO) de polpa de pinha (Annona squamosa L.) madura. Ciência e Tecnologia de Alimentos, Campinas, v.21, n.1, p. 98-104, 2001.

LOPES, R. L. T. Manual para fabricação de geleias. Belo Horizonte: Fundação Centro Tecnológico de Minas Gerais, 1985. 42 p. (Série de Publicações Técnicas).

MACIEL, M. I. S. et al. Características sensoriais e físico-químicas de geléias mistas de manga e acerola, Boletim do CEPPA, Curitiba, v.27, n.2, p.247-256, 2009.

MARCELLINI, P. S. et al. Comparação físico-química e sensorial da atemóia com a pinha e a graviola produzidas e comercializadas no estado de Sergipe. Alimentos e Nutrição, Araraquara, v.14, n.2, p. 187-189, 2003.

MILLER, G. L. Use of dinitrosalicylic acid reagent for determination of reducing sugar. Analytical Chemistry, Washington, v.31, n.4, p.426, 1959.

MONTEIRO, C. L. B. Técnicas de avaliação sensorial. 2 ed. Curitiba: CEPPA, 1984. 101P.

NEVES, C. S. V. J.; YUHARA, E. N. Caracterização dos frutos de cultivares de atemóia produzidos no norte do Paraná, Semina: Ciências Agrárias, Londrina, v.24, n.2, p.311-314, 2003.

NWOKOCHA, L. M.; WILLIAMS, P. A. New starches: Physicochemical properties of sweetsop (Annona squamosa) and soursop (Anonna muricata) starches. Carbohydrate Polymers, Barking, v.78, p.462-468, 2009.

SACRAMENTO, C. K. et al. Caracterização física e química de frutos de três tipos de gravioleira (Annona muricata L.), Revista Brasileira de Fruticultura, Jaboticabal, v.25, n. 2, p.329-331, 2003.

SILVA, A. V. et al. Uso de embalagens e refrigeração na conservação de atemóia, Ciência e Tecnologia de Alimentos, Campinas, v.29, n. 2, p. 300-304, 2009.

SILVA, R. N. et al. Comparação de métodos para a determinação de açúcares redutores e totais em mel. Ciência e Tecnologia de Alimentos, Campinas, v.23, n. 3, p.337-341, 2003.

SINGH, S. et al. Quality changes in fruit jams from combinations of different fruit pulps, Journal of Food Processing and Preservation, Westport, v.33, n.1, p.41$57,2009$.

STONE, H.; SIDEL, J. Sensory evaluation practices. New York: Academic Press, 1993. p.338

TEIXEIRA, E; MEINERT, E; BARBETTA, P. A. Análise sensorial dos alimentos, Florianópolis: Ed. UFSC, 1987, $182 \mathrm{p}$.

UMME, A. et al. Effect of pasteurisation on sensory quality of natural soursop puree under different storage conditions, Food Chemistry, Barking, v.75, n.3, p.293301, 2001.

WILSON, E. D.; SANTOS, A. C.; VIEIRA, E. C. Energia. In: DUTRA-OLIVEIRA, J. E.; SANTOS, A. C.; WILSON, E. D. Nutrição Básica. São Paulo: Sarvier, p.80-94, 1982. 